\title{
ANALISIS KEMAMPUAN KONEKSI MATEMATIS DITINJAU DARI SELF CONFIDENCE SISWA : STUDI KASUS DI SMKN 4 PANDEGLANG
}

\author{
Atika Nurafni $^{1 \bowtie}$ dan Heni Pujiastuti $^{2}$ \\ ${ }^{1,2}$ Prodi Pendidikan Matematika, Universitas Sultan Ageng Tirtayasa
}

\section{Sejarah Artikel:}

Diterima 19 Feb 2019

Direvisi 22 Mei 2019

Disetujui $25 \mathrm{Mei}$

2019

\section{Keywords:}

Kemampuan koneksi

matematis, Self-

confidence

Paper type:

Research paper

\begin{abstract}
This study aims to describe the extent of mathematical connection skills in terms of student selfconfidence, especially in the Linear Program material. The subjects of this study were as many as 30 tenth grade students of SMK 4 Pandeglang Light Vehicle Engineering Department. The method used in this study is descriptive method with a quantitative approach. The instruments used in this study include the test of mathematical connection ability and self-confidence questionnaire. The research was conducted in three stages, namely preparation, implementation and analysis of data. The results showed that: 1) Overall the mathematical connection ability of students gained an average of 65\% which was included in the sufficient category, 2) Students with high self-confidence, the average mathematical connection ability was 86\% which was included in the excellent category, 3 ) Students with moderate self-confidence, the average mathematical connection ability is $63 \%$ which is included in the sufficient category, and 4) Students with low self-confidence, the average mathematical connection ability is $47 \%$ which is included in the less category.
\end{abstract}

\begin{abstract}
Abstrak
Penelitian ini bertujuan untuk mendeskripsikan sejauh mana kemampuan koneksi matematis ditinjau dari self-confidence siswa, khususnya pada materi Program Linier. Subyek penelitian ini yaitu sebanyak 30 siswa kelas X SMKN 4 Pandeglang Jurusan Teknik Kendaraan Ringan. Metode yang digunakan dalam penelitian ini yaitu metode deskriptif dengan pendekatan kuantitatif. Instrumen yang digunakan dalam penelitian ini diantaranya yaitu tes kemampuan koneksi matematis dan angket selfconfidence. Penelitian yang dilakukan dalam tiga tahap yaitu persiapan, pelaksanaan dan analisis data. Hasil penelitian menunjukkan bahwa : 1) Secara keseluruhan kemampuan koneksi matematis siswa memperoleh rata-rata $65 \%$ yang termasuk dalam kategori cukup, 2) Siswa dengan self-confidence tinggi, rata-rata kemampuan koneksi matematisnya $86 \%$ yang termasuk kedalam kategori sangat baik, 3) Siswa dengan self-confidence sedang, rata-rata kemampuan koneksi matematisnya $63 \%$ yang termasuk kedalam kategori cukup, dan 4) Siswa dengan self-confidence rendah, rata-rata kemampuan koneksi matematisnya $47 \%$ yang termasuk dalam kategori kurang.
\end{abstract}

(C) 2019 Universitas Muria Kudus

\begin{tabular}{lc}
\hline Alamat korespondensi: & p-ISSN 2615-4196 \\
Program Studi Pendidikan Matematika & e-ISSN 2615-4072 \\
Fakultas Keguruan dan Ilmu Pendidikan Universitas Muria Kudus & \\
Kampus UMK Gondangmanis, Bae Kudus Gd. L. It I PO. BOX 53 Kudus & \\
Tlp (0291) 438229 ex.175 Fax. (0291) 437198 & \\
E-mail: atikanurafni@gmail.com &
\end{tabular}


Atika Nurafni dan Heni Pujiastuti

\section{PENDAHULUAN}

Dalam kurikulum matematika, ide-ide matematis saling terkait dan membangun satu sama lain sehingga pemahaman dan pengetahuan siswa mendalam serta kemampuan siswa untuk menerapkan matematika berkembang (National Council of Teachers of Mathematics, 2000). Pada hakikatnya matematika adalah ilmu yang terorganisir secara matematis dan konsepkonsepnya memiliki hubungan satu dengan yang lainnya. Hubungan antar konsep di dalam matematika lebih dikenal dengan istilah koneksi matematis. Koneksi matematis merupakan satu dari kemampuan matematis yang perlu dimiliki dan dikembangkan pada siswa sekolah menengah. Matematika sebagai ilmu bantu menunjukkan bahwa konsep-konsep matematika banyak digunakan dalam pengembangan bidang studi lain dan penyelesaian masalah sehari-hari. Pada dasarnya setiap anak memiliki kemampuan koneksi matematis, hanya saja kadarnya yang berbeda-beda (Puteri \& Riwayati, 2017). Seseorang yang memahami kaitan antar konsep matematika dengan baik, maka ia tidak hanya hapal atau mengingat konsep dalam jangka pendek namun penguasaan konsepnya lebih tahan lama dan ia mampu menerapkan konsep pada situasi lain.

$$
\text { Beberapa penulis mengemukakan }
$$
pengertian istilah koneksi matematis dalam ungkapan yang berbeda-beda Koneksi matematis adalah interelasi antara situasi, masalah, dan ide-ide matematis dan menerapkan pengetahuan yang telah diperoleh dalam menyelesaikan masalah yang satu dengan masalah lainnya (Maisyarah \& Surya, 2017). Koneksi matematis merupakan keterkaitan ide-ide, konsep, prinsip, teorema dan keterkaitan kosep matematis dengan bidang lain atau masalah dalam sehari-hari. Sedangkan kemampuan koneksi matematis adalah kemampuan mengaitkan ide-ide matematis dalam satu konsep dengan konsep lainnya pada saat menyelesaikan masalah. Agar siswa dapat melakukan koneksi maka siswa harus memahami informasi-informasi yang diterimanya terlebih dahulu sehingga dapat mengaitkan ide-ide matematis (Defitriani, 2018).

Menurut NCTM (2000: 64) program pembelajaran dari TK sampai kelas 12 harus memungkinkan siswa untuk mampu: (1) mengenal dan membuat koneksi antara ide-ide matematika (2) memahami bagaimana membangun ide-ide matematika, selanjutnya ide-ide tersebut dikoneksikan dengan ilmu lain (3) mengenal dan mengaplikasikan ide-ide matematika ke dalam kehidupan sehari-hari. Koneksi matematika dalam NCTM dibagi ke dalam tiga aspek kelompok koneksi yaitu aspek koneksi antar topik matematika, koneksi dengan disiplin ilmu lain dan koneksi dengan kehidupan sehari-hari. Pada aspek koneksi antar topik matematika dapat membantu siswa menghubungkan konsep-konsep matematika untuk menyelesaikan suatu situasi permasalahan matematika. Pada aspek koneksi dengan disiplin ilmu lain menunjukkan bahwa matematika sebagai suatu disiplin ilmu, selain dapat berguna untuk pengembangan disiplin ilmu yang lain, juga dapat berguna untuk menyelesaikan suatu permasalahan yang berkaitan dengan bidang studi lainnya. Pada aspek koneksi dengan kehidupan sehari-hari menunjukkan bahwa matematika dapat bermanfaat untuk menyelesaikan suatu permasalahan di kehidupan sehari-hari.

Berdasarkan pengertian koneksi matematis NCTM (2000) merangkum indikator koneksi matematis dalam tiga komponen besar, yaitu : (Hendriana, Rohaeti, \& Sumarmo, 2017)

1. Mengenali dan menggunakan hubungan antar ide-ide dalam matematika,

2. Memahami keterkaitan ide-ide matematika dan membentuk ide matematika baru yang lain sehingga menghasilkan suatu keterkaitan menyeluruh,

3. Mengenali dan mengaplikasikan satu konten matematika ke dalam konten matematika lain dan ke lingkungan di luar matematika.

Pada penelitian yang saya lakukan indikator yang diambil yaitu: 1) menggunakan konsep matematika dalam kehidupan sehari-hari, 2) Menggunakan konsep matematika dalam bidang lain, dan 3) Menggunakan koneksi antar topic matematika.

Kemampuan untuk menyelesaikan masalah matematis merupakan kemampuan yang penting untuk dikuasai dalam kehidupan sehari-hari. Pemikiran matematika adalah sesuatu yang kita lakukan mulai dari perhitungan yang sederhana hingga kompleks. Ketika matematika disebutkan, banyak orang akan bicara bahwa mereka tidak memiliki kemampuan bermatematika yang baik, takut terhadap matematika atau tidak suka matematika. Mengapa sebagian orang merasa matematika itu mudah dan sebagian yang lain mengatakan matematika itu sulit ? Hal ini berpengaruh pada self-confidence atau kepercayaan diri seseorang pada kemampuan dirinya. Contohnya, jika siswa percaya akan kemampuan dirinya mereka akan lebih banyak bertanya atau menjawab pertanyaan lebih sering daripada siswa yang tidak percaya akan kemampuan dirinya, mereka akan lebih banyak diam dan cenderung takut. Tentunya hal ini akan mempengaruhi belajar mengajar (Koriyah \& Harta, 2015). 
Kepercayaan diri merupakan kepercayaan setiap individu terhadap kemampuan yang dimiliki serta merasa yakin dan benar atas apa yang dilakukan dirinya sendiri. Menurut Haeruman, yang dikutip dari Rahayu dan Ambarwati (2017:160) bahwa self-confidence adalah pembentukan pemahaman berdasarkan keyakinan dan perasaan siswa tentang kemampuan dirinya (Pitriyani, Fitrianna, Malinda, \& Hajar, 2018). Menurut Utari dalam bukunya mengemukakan beberapa indikator kepercayaan diri antara lain: 1) Percaya kepada kemampuan sendiri, tidak cemas, merasa bebas dan bertanggungjawab atas perbuatannya; 2) Bertindak mandiri dalam mengambil keputusan; 3) Memiliki konsep diri yang positif, hangat dan sopan, dapat menghargai dan menerima orang lain; 4) Memiliki dorongan untuk berprestasi serta berani mengungkapkan pendapat; 5) Mengenal diri sendiri atas kelebihan dan kekurangan yang dimiliki (Hendriana et al., 2017).

Berdasarkan uraian diatas, kemampuan koneksi matematis dipengaruhi oleh pengetahuan sebelumnya dan self-confidence siswa. Antara kemampuan koneksi matematis dan self-confidence memiliki korelasi yang moderat (Hendriana, Slamet, \& Sumarmo, 2014). Hal ini juga di kemukakan oleh (Nurhayati, 2014) tentang fakta bahwa kemampuan koneksi matematis dan selfconfidence siswa merupakan aspek yang penting dalam pembelajaran matematika. Pada penelitian yang dilakukan oleh Pipit Pitriyani menyatakan bahwa kemampuan koneksi matematis ditinjau dari self-confidence siswa MTs masih rendah (Pitriyani dkk, 2018). Sehingga dipandang perlu untuk mengkaji dan meneliti kemampuan koneksi matematis dan self-confidence pada pembelajaran matematika. Oleh sebab itu peneliti ingin meneliti tentang kemampuan koneksi matematis ditinjau dari self-confidence pada siswa SMK, karena pada usia ini siswa sudah dewasa dan seharusnya memiliki self-confidence yang kuat. Sesuai dengan uraian diatas tujuan dari penelitian ini adalah untuk mendeskripsikan kemampuan koneksi matematis ditinjau dari self- confidence siswa khusunya pada materi program linier yang dilakukan di SMK Negeri 4 Pandeglang.

\section{METODE PENELITIAN}

Pendekatan yang digunakan dalam penelitian ini adalah pendekatan kuantitatif dengan jenis penelitian deskriptif dengan bentuk penelitian studi kasus (Lestari \& Yudhanegara, 2015). Populasi dalam penelitian ini adalah siswa SMKN 4 Pandeglang, Banten. Sedangkan sampelnya sebanyak 30 siswa laki-laki kelas X Jurusan Teknik Kendaraan Ringan (TKR). Instrumen dalam penelitian ini adalah peneliti sendiri, dimana peneliti sebagai perencana, pelaksana, pengumpul data, penganalisis dan penafsir data. Selain itu instrument yang lain ialah notes yaitu berupa angket self-confidence dengan 33 pertanyaan dan juga soal tes kemampuan koneksi matematis dengan 3 soal tes essai (Hidayat, Tresnawati, \& Euis Eti Rohaeti, 2017). Prosedur yang dilakukan dalam penelitian ini terdiri dari tiga tahap, yaitu : 1. Tahap persiapan, 2. Tahap pelaksanaan, 3. Analisis data. Kategori pengelompokan self-confidence dengan pemberian skor untuk tiap jawaban angket positif dan negative dapat dilihat pada Tabel 1 .

Tabel 1. Skor jawaban angket self-confidence

\begin{tabular}{lcc}
\hline Jawaban & Positif & Negatif \\
\hline Sangat Sering & 4 & 1 \\
Sering & 3 & 2 \\
Jarang & 2 & 3 \\
Jarang Sekali & 1 & 4 \\
\hline
\end{tabular}

Berdasarkan hasil skoring angket selfconfidence dapat dikelompokkan menurut skala yaitu: (1) Skor 100-132 memiliki rasa percaya diri tinggi; (2) Skor 67-99 memiliki rasa percaya diri sedang; dan (3) Skor 33-66 memiliki rasa percaya diri rendah. Sedangkan skor untuk tes kemampuan koneksi matematis beserta alternative jawaban, penskoran berdasarkan ktriteria kemampuan koneksi matematis yang diungkapkan menurut lane (Suhandri, Nufus, \& Nurdin, 2017). Dapat dilihat pada Tabel 2 berikut:

Tabel 2. Kriteria pedoman penskoran kemampuan koneksi matematis

\begin{tabular}{ll}
\hline Skor & Kriteria jawaban dan alas an \\
\hline 4 & $\begin{array}{l}\text { Menunjukkan pemahaman terhadap konsep dan } \\
\text { proses matematis soal, menggunakan istilah dan } \\
\text { notasi yang tepat, melaksanakan algoritma secara } \\
\text { benar dan lengkap. }\end{array}$ \\
\hline & Pemahaman yang baik terhadap konsep dan \\
& proses matematis soal, menggunakan istilah dan \\
& notasi yang hampir benar, melaksanakan \\
& algoritma secara lengkap dan secara umum \\
& perhitungan benar, tetapi masih terdapat \\
& kesalahan. \\
& Hampir memahami konsep dan proses \\
& matematis soal, mengidentifikasi unsur-unsur \\
& penting, namun banyak ide-ide yang keliru, \\
& melakukan beberapa kesalahan perhitungan. \\
\hline & $\begin{array}{l}\text { Memahami sebagian konsep dan proses } \\
\text { matematis soal, menggunakan alat dan strategi }\end{array}$ \\
& penyelesaian yang tidak tepat dan melakukan \\
& banyak kesalahan perhitungan.
\end{tabular}

Skor ideal 4 pada setiap soal 
Kategori kemampuan koneksi matematis pada penelitian ini dimodifikasi dari pengkategorian skor tes yang dinyatakan oleh Arikunto (Suhandri et al., 2017), dapat di lihat pada Table 3.

Tabel 3. Kategori kemampuan koneksi matematis

\begin{tabular}{ll}
\hline Kategori & Rentang Skor \\
\hline Sangat Baik & $3,40<$ skor $\leq 4$ \\
Baik & $3,00<$ skor $\leq 3,40$ \\
Cukup & $2,40<$ skor $\leq 3,00$ \\
Kurang & $1,80<$ skor $\leq 2,40$ \\
Kurang Sekali & $0<$ skor $\leq 1,80$ \\
\hline
\end{tabular}

\section{HASIL DAN PEMBAHASAN}

Setelah melakukan penelitian dengan memberikan angket self-confidence dan tes kemampuan koneksi matematis, hasil diperoleh sebagai berikut:

1. Pengelompokan Self-Confidence

Hasil pengelompokan self-confidence diperoleh dengan menggunakan skala dari jumlah skor sesuai dengan Tabel 4, dan hasilnya sebagai berikut

Table 4. Kelompok Self-Confidence

\begin{tabular}{cc}
\hline Kelompok Self-confidence & Jumlah Siswa \\
\hline Tinggi & 7 \\
Sedang & 15 \\
Rendah & 8 \\
\hline
\end{tabular}

Berdasarkan Tabel 4 dapat dilihat bahwa jumlah siswa yang mengikuti tes berjumlah 30 siswa, setelah skor tes angket dihitung berdasarkan skor maka diperoleh hasil dengan kelompok kepercayaan diri siswa tinggi berjumlah 7 siswa, kelompok kepercayaan diri sedang berjumlah 15 siswa, dan kelompok kepercayaan diri rendah berjumlah 8 siswa.

2. Skor kemampuan koneksi matematik ditinjau dari level self-confidence

Penelitian tes kemampuan koneksi matematis berbentuk essai, terdiri dari 3 soal dengan aspek yang berbeda yaitu mengkoneksikan konsep matematika ke dalam kehidupan sehari-hari (soal no 1), menggunakan konsep matematika dengan mata pelajaran lain (soal no 2), dan mengkoneksikan antar topic matematika (soal no 3). Selanjutnya hasil skor tes kemampuan koneksi matematis siswa dikategorikan berdasarkan kelompok selfconfidence, dan dapat dilihat pada table 4 berikut ini.

Tabel 4. Hasil skor tes kemampuan koneksi matematis pada setiap soal

\begin{tabular}{ccccc}
\hline Kelompok & \multicolumn{3}{c}{ Nomor soal } & Rata-rata \\
\cline { 2 - 4 } $\begin{array}{c}\text { Self- } \\
\text { confidence }\end{array}$ & $\mathbf{1}$ & $\mathbf{2}$ & $\mathbf{3}$ & \\
\hline Tinggi & 3,86 & 3,57 & 2,86 & 3,43 \\
Sedang & 3,20 & 2,67 & 1,60 & 2,49 \\
Rendah & 2,88 & 1,88 & 0,88 & 1,88 \\
\hline Keseluruhan & 3,31 & 2,66 & 1,78 & 2,60 \\
\hline
\end{tabular}

Tabel 4 menunjukkan bahwa skor rata-rata kemampuan koneksi matematis secara keseluruhan berada pada kategori cukup, yaitu dengan skor ratarata 2,60. Berdasarkan kelompok self-confidence menunjukkan bahwa siswa dengan self-confidence tinggi memiliki kemampuan koneksi matematis dengan kategori sangat baik dengan skor rata-rata 3,43 , siswa yang memiliki self-confidence sedang memiliki kemampuan koneksi matematis cukup dengan skor rata-rata 2,49 , dan siswa yang memiliki self confidence rendah memiliki kemampuan matematis kurang dengan skor rata-rata 1,88.

Tabel 5. Distribusi skor tes kemampuan koneksi matematis berdasarkan self-confidence

\begin{tabular}{lcccc}
\hline \multirow{2}{*}{$\begin{array}{c}\text { Kelompok } \\
\text { Self- } \\
\text { confidence }\end{array}$} & $\begin{array}{c}\text { Jumlah } \\
\text { siswa } \\
\text { mendapat } \\
\text { skor }\end{array}$ & $\mathbf{4}$ & \multicolumn{4}{c}{ No Soal } \\
\cline { 3 - 5 } & 4 & 6 & 5 & 2 \\
Tinggi & 3 & 1 & 1 & 3 \\
& 2 & 0 & 1 & 2 \\
Jumlah & 1 & 0 & 0 & 1 \\
& 0 & 0 & 0 & 0 \\
Sedang & 4 & 5 & 3 & 1 \\
& 3 & 8 & 5 & 2 \\
Jumlah & 2 & 2 & 6 & 3 \\
& 1 & 0 & 1 & 8 \\
Rendah & 0 & 0 & 0 & 1 \\
& & & 15 & \\
\hline \multirow{3}{*}{ Jumlah } & 3 & 2 & 0 & 0 \\
\hline
\end{tabular}

Berdasarkan Tabel dan Tabel 5, kemampuan koneksi matematis siswa dengan kelompok self-confidence tinggi dapat dijelaskan sebagai berikut:

a. Siswa kelompok self-confidence tinggi memiliki kemampuan koneksi matematis yang sangat baik dalam aspek memahami konsep matematika dalam kehidupan seharihari (soal no 1) terdapat 6 siswa $(86 \%)$ dapat menunjukkan pemahaman terhadap konsep dan proses matematis soal, menggunakan istilah dan notasi yang tepat, melaksanakan algoritma secara benar dan lengkap dan 1 siswa (14\%) dapat memahami dengan baik konsep dan proses matematis soal, menggunakan istilah dan notasi yang hampir benar, melaksanakan algoritma secara lengkap dan secara umum perhitungan benar, tetapi masih terdapat kesalahan.

b. Siswa kelompok self-confidence tinggi memiliki kemampuan koneksi matematis 
yang sangat baik dalam aspek memahami konsep matematika dengan mata pelajaran lain (soal no 2) terdapat 5 siswa $(72 \%)$ dapat menunjukkan pemahaman terhadap konsep dan proses matematis soal, menggunakan istilah dan notasi yang tepat, melaksanakan algoritma secara benar dan lengkap, 1 siswa (14\%) dapat memahami dengan baik konsep dan proses matematis soal, menggunakan istilah dan notasi yang hampir benar, melaksanakan algoritma secara lengkap dan secara umum perhitungan benar, tetapi masih terdapat kesalahan, dan 1 siswa (14\%) hampir memahami konsep dan proses matematis soal, mengidentifikasi unsur-unsur penting, namun banyak ide-ide yang keliru, melakukan beberapa kesalahan perhitungan.

c. Siswa kelompok self-confidence tinggi memiliki kemampuan koneksi matematis yang cukup dalam aspek menggunakan koneksi antar topic matematika (soal no 3) terdapat 2 siswa (28\%) dapat menunjukkan pemahaman terhadap konsep dan proses matematis soal, menggunakan istilah dan notasi yang tepat, melaksanakan algoritma secara benar dan lengkap, 3 siswa (42\%) dapat memahami dengan baik konsep dan proses matematis soal, menggunakan istilah dan notasi yang hampir benar, melaksanakan algoritma secara lengkap dan secara umum perhitungan benar, tetapi masih terdapat kesalahan, 2 siswa (28\%) hampir memahami konsep dan proses matematis soal, mengidentifikasi unsur-unsur penting, namun banyak ide-ide yang keliru, melakukan beberapa kesalahan perhitungan, dan 1 siswa (14\%) dapat memahami sebagian konsep dan proses matematis soal, menggunakan alat dan strategi penyelesaian yang tidak tepat dan melakukan banyak kesalahan perhitungan.

Untuk kemampuan koneksi matematis dengan self-confidence sedang dapat dijelaskan sebagai berikut:

a. Siswa kelompok self-confidence sedang memiliki kemampuan koneksi matematis yang baik dalam aspek memahami konsep matematika dalam kehidupan sehari-hari (soal no 1) terdapat 5 siswa $(30 \%)$ dapat menunjukkan pemahaman terhadap konsep dan proses matematis soal, menggunakan istilah dan notasi yang tepat, melaksanakan algoritma secara benar dan lengkap, 8 siswa (53\%) dapat memahami dengan baik konsep dan proses matematis soal, menggunakan istilah dan notasi yang hampir benar, melaksanakan algoritma secara lengkap dan secara umum perhitungan benar, tetapi masih terdapat kesalahan, dan 2 siswa (17\%) hampir memahami konsep dan proses matematis soal, mengidentifikasi unsur-unsur penting, namun banyak ide-ide yang keliru, melakukan beberapa kesalahan perhitungan.

b. Siswa kelompok self-confidence sedang memiliki kemampuan koneksi matematis yang cukup dalam aspek memahami konsep matematika dengan mata pelajaran lain (soal no 2) terdapat 3 siswa $(20 \%)$ dapat menunjukkan pemahaman terhadap konsep dan proses matematis soal, menggunakan istilah dan notasi yang tepat, melaksanakan algoritma secara benar dan lengkap, 5 siswa (30\%) dapat memahami dengan baik konsep dan proses matematis soal, menggunakan istilah dan notasi yang hampir benar, melaksanakan algoritma secara lengkap dan secara umum perhitungan benar, tetapi masih terdapat kesalahan, 6 siswa (40\%) hampir memahami konsep dan proses matematis soal, mengidentifikasi unsur-unsur penting, namun banyak ide-ide yang keliru, melakukan beberapa kesalahan perhitungan, dan 1 siswa (10\%) dapat memahami sebagian konsep dan proses matematis soal, menggunakan alat dan strategi penyelesaian yang tidak tepat dan melakukan banyak kesalahan perhitungan.

c. Siswa kelompok self-confidence sedang memiliki kemampuan koneksi matematis yang sangat kurang dalam aspek menggunakan koneksi antar topic matematika (soal no 3) terdapat 1 siswa $(6,7 \%)$ dapat menunjukkan pemahaman terhadap konsep dan proses matematis soal, menggunakan istilah dan notasi yang tepat, melaksanakan algoritma secara benar dan lengkap, 2 siswa $(13,3 \%)$ dapat memahami dengan baik konsep dan proses matematis soal, menggunakan istilah dan notasi yang hampir benar, melaksanakan algoritma secara lengkap dan secara umum perhitungan benar, tetapi masih terdapat kesalahan, 3 siswa (10\%) hampir memahami konsep dan proses matematis soal, mengidentifikasi unsur-unsur penting, namun banyak ide-ide yang keliru, melakukan beberapa kesalahan perhitungan, 8 siswa $(53,3 \%)$ dapat memahami sebagian konsep dan proses matematis soal, menggunakan alat dan strategi penyelesaian yang tidak tepat dan melakukan banyak kesalahan perhitungan, dan 1 siswa $(6,7 \%)$ tidak menjawab soal. 
Untuk kemampuan koneksi matematis dengan self-confidence rendah dapat dijelaskan sebagai berikut:

a. Siswa kelompok self-confidence rendah memiliki kemampuan koneksi matematis yang cukup dalam aspek memahami konsep matematika dalam kehidupan sehari-hari (soal no 1) terdapat 2 siswa $(25 \%)$ dapat menunjukkan pemahaman terhadap konsep dan proses matematis soal, menggunakan istilah dan notasi yang tepat, melaksanakan algoritma secara benar dan lengkap, 3 siswa $(37.5 \%)$ dapat memahami dengan baik konsep dan proses matematis soal, menggunakan istilah dan notasi yang hampir benar, melaksanakan algoritma secara lengkap dan secara umum perhitungan benar, tetapi masih terdapat kesalahan, dan 3 siswa $(37,5 \%)$ hampir memahami konsep dan proses matematis soal, mengidentifikasi unsur-unsur penting, namun banyak ide-ide yang keliru, melakukan beberapa kesalahan perhitungan.

b. Siswa kelompok self-confidence rendah memiliki kemampuan koneksi matematis yang sangat kurang dalam aspek memahami konsep matematika dengan mata pelajaran lain (soal no 2) tidak ada siswa yang dapat menunjukkan pemahaman terhadap konsep dan proses matematis soal, menggunakan istilah dan notasi yang tepat, melaksanakan algoritma secara benar dan lengkap. terdapat 2 siswa $(25 \%)$ dapat memahami dengan baik konsep dan proses matematis soal, menggunakan istilah dan notasi yang hampir benar, melaksanakan algoritma secara lengkap dan secara umum perhitungan benar, tetapi masih terdapat kesalahan, 3 siswa $(37,5 \%)$ hampir memahami konsep dan proses matematis soal, mengidentifikasi unsur-unsur penting, namun banyak ide-ide yang keliru, melakukan beberapa kesalahan perhitungan, dan 3 siswa $(37,5 \%)$ dapat memahami sebagian konsep dan proses matematis soal, menggunakan alat dan strategi penyelesaian yang tidak tepat dan melakukan banyak kesalahan perhitungan.

c. Siswa kelompok self-confidence sedang memiliki kemampuan koneksi matematis yang sangat kurang dalam aspek menggunakan koneksi antar topic matematika (soal no 3) terdapat 1 siswa $(12,5 \%)$ hampir memahami konsep dan proses matematis soal, mengidentifikasi unsur-unsur penting, namun banyak ide-ide yang keliru, melakukan beberapa kesalahan perhitungan, 5 siswa $(62,5 \%)$ dapat memahami sebagian konsep dan proses matematis soal, menggunakan alat dan strategi penyelesaian yang tidak tepat dan melakukan banyak kesalahan perhitungan, dan 2 siswa (25\%) tidak menjawab soal.

Hasil penelitian secara keseluruhan dapat disimpulkan melalui rangkuman kemampuan koneksi matematis ditinjau dari self-confidence berikut:

Tabel 6 Persentase kemampuan koneksi matematis secara keseluruhan

\begin{tabular}{|c|c|c|c|c|c|}
\hline \multirow{2}{*}{$\begin{array}{l}\text { Kelompok } \\
\text { Self- } \\
\text { confidence }\end{array}$} & \multicolumn{3}{|c|}{ Indikator soal } & \multirow{2}{*}{$\begin{array}{c}\text { Total } \\
\text { persentas } \\
\text { e(\%) skor }\end{array}$} & \multirow{2}{*}{$\begin{array}{c}\text { Kategori } \\
\text { koneksi } \\
\text { matematis }\end{array}$} \\
\hline & 1 & 2 & 3 & & \\
\hline Tinggi & 96 & 89 & 79 & 86 & Sangat baik \\
\hline Sedang & 80 & 67 & 40 & 63 & Cukup \\
\hline Rendah & 72 & 47 & 22 & 47 & Kurang \\
\hline $\begin{array}{l}\text { Keseluruh } \\
\text { an } \\
\end{array}$ & 83 & 68 & 47 & 65 & $\mathrm{p}$ \\
\hline
\end{tabular}

Berdasarkan tabel 6, dapat disimpulkan sebagai berikut: 1) Secara keseluruhan kemampuan koneksi matematis siswa memperoleh rata-rata $65 \%$ yang termasuk dalam kategori cukup, 2) Siswa dengan self-confidence tinggi, rata-rata kemampuan koneksi matematisnya $86 \%$ yang termasuk kedalam kategori sangat baik, 3) Siswa dengan self-confidence sedang, rata-rata kemampuan koneksi matematisnya 63\% yang termasuk kedalam kategori cukup, dan 4) Siswa dengan self-confidence rendah, rata-rata kemampuan koneksi matematisnya $47 \%$ yang termasuk dalam kategori kurang.

Kemampuan koneksi matematis dalam menyelesaikan soal-soal program linier ditinjau dari self-confidence, secara keseluruhan adalah cukup dengan persentase 65\%. Terdapat perbedaan hasil dari penelitian yang dilakukan sebelumnya menyatakan bahwa kemampuan koneksi matematis ditinjau dari self-confidence masih rendah (Pitriyani et al., 2018).

\section{SIMPULAN}

Berdasarkan hasil dan pembahasan yang telah dilakukan, diperoleh kesimpulan umum bahwa kemampuan koneksi matematis pada materi program linier, untuk kelompok self-confidence tinggi termasuk dalam kategori sangat baik, untuk kelompok self-confidence sedang termasuk dalam kategori cukup, dan untuk kelompok selfconfidence rendah termasuk dalam kategori kurang. Sehingga kemampuan koneksi matematis siswa sesuai dengan kelompok self-confidence, karena kemampuan untuk mengkoneksikan dalam 
matematika dilakukan secara individual dan selfconfidence dapat memperkuat motivasi untuk mencapai keberhasilan.

Adapun saran yang ingin peneliti sampaikan untuk peneliti yang lain, diharapkan dapat melaksanakan penelitian lanjutan mengenai koneksi matematis sehingga dapat memperbaiki kemampuan koneksi matematis siswa. Dan khususnya untuk guru SMKN 4 Pandeglang, lebih memperhatikan dan mencari cara agar selfconfidence siswa dapat berkembang secara optimal.

\section{UCAPAN TERIMAKASIH}

Penulis ucapkan terima kasih kepada siswa SMKN 4 Pandeglang, yang telah membantu dan bekerjasama dalam pelaksanaan penelitian hingga penulisan artikel ini selesai. Penulis juga mengucapkan terimakasih kepada segenap tim Pengelola Jurnal Anargya yang telah memberi kesempatan kepada penulis untuk mempublikasi artikel ini.

\section{DAFTAR PUSTAKA}

Defitriani, E. 2018. Mengembangkan Kemampuan Koneksi Matematis Siswa Melalui Pendekatan Differentiated Instruction. Anargya: Jurnal Ilmiah Pendidikan Matematika, 1(2), 72-76.

Hendriana, H., Rohaeti, E. E., \& Sumarmo, U. 2017. Hard Skills dan Soft Skills Matematik Siswa. (N. F. Atif, Ed.) (kesatu). Bandung: PT Refika Aditama.

Hendriana, H., Slamet, R., \& Sumarmo, U. 2014. Mathematical Conection Ability AND SelfConfidence (An experiment on Junior High School students through Contextual Teaching and learning with Mathematical Manipulative). International Journal of Education, 8, 1-11.

Hidayat, W., Tresnawati, \& Euis Eti Rohaeti. 2017. Kemampuan Berpikir Kritis Matematis dan Kepercayaan Diri Siswa SMA. Journal of Research in Mathematics Learning and Education, 2(2), 116-122.

Koriyah, V. N., \& Harta, I. 2015. Pengaruh OpenEnded terhadap Prestasi Belajar, Berpikir Kritis dan Kepercayaan Diri Siswa SMP. Phytagoras: Jurnal Pendidikan Matematika, 10(1), 95-105.

Lestari, K. E., \& Yudhanegara, M. R. 2015. Penelitian Pendidikan Matematika. Bandung: PT Refika Aditama.

Maisyarah, R., \& Surya, E. 2017. Kemampuan

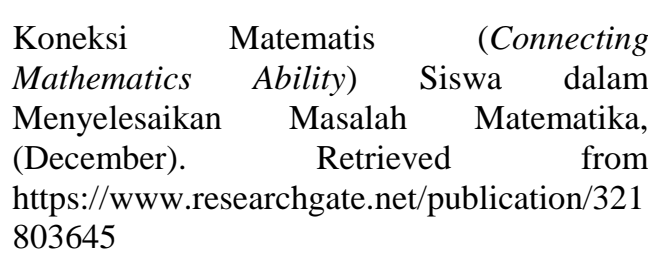

National Council of Teachers of Mathematics (NCTM). 2000. Six Principles for School Mathematics: Executive Summary. https://doi.org/10.1111/j.19498594.2001.tb17957.x

Nurhayati, A. 2014. Meningkatkan Kemampuan Koneksi Matematis, Self-Confidence Siswa Melalui Penerapan Pendekatan Pembelajaran Saintifik Berbantuan Persoalan Open-Ended (Tesis). Bandung : Universitas Pendidikan Indonesia.

Pitriyani, P., Fitrianna, A. Y., Malinda, P., \& Hajar, M. S. 2018. Analisis Kemampuan Koneksi Matematik Siswa MTs Ditinjau Dari Self Confidence. JPPM: Jurnal Penelitian Dan Pembelajaran Matematika, 11(1). https://doi.org/http://dx.doi.org/10.30870/jpp m.v11i1.2989

Puteri, J. W., \& Riwayati, S. 2017. Kemampuan koneksi matematis siswa pada model pembelajaran conneted mathematics project (cmp). Fibonacci, 3(2), 161-168.

Suhandri, S., Nufus, H., \& Nurdin, E. 2017. Profil Kemampuan Koneksi Matematis Mahasiswa dalam Menyelesaikan Masalah Matematika Berdasarkan Level Kemampuan Akademik. Jurnal Analisa, 3(2), 115. https://doi.org/10.15575/ja.v3i2.2012 